4

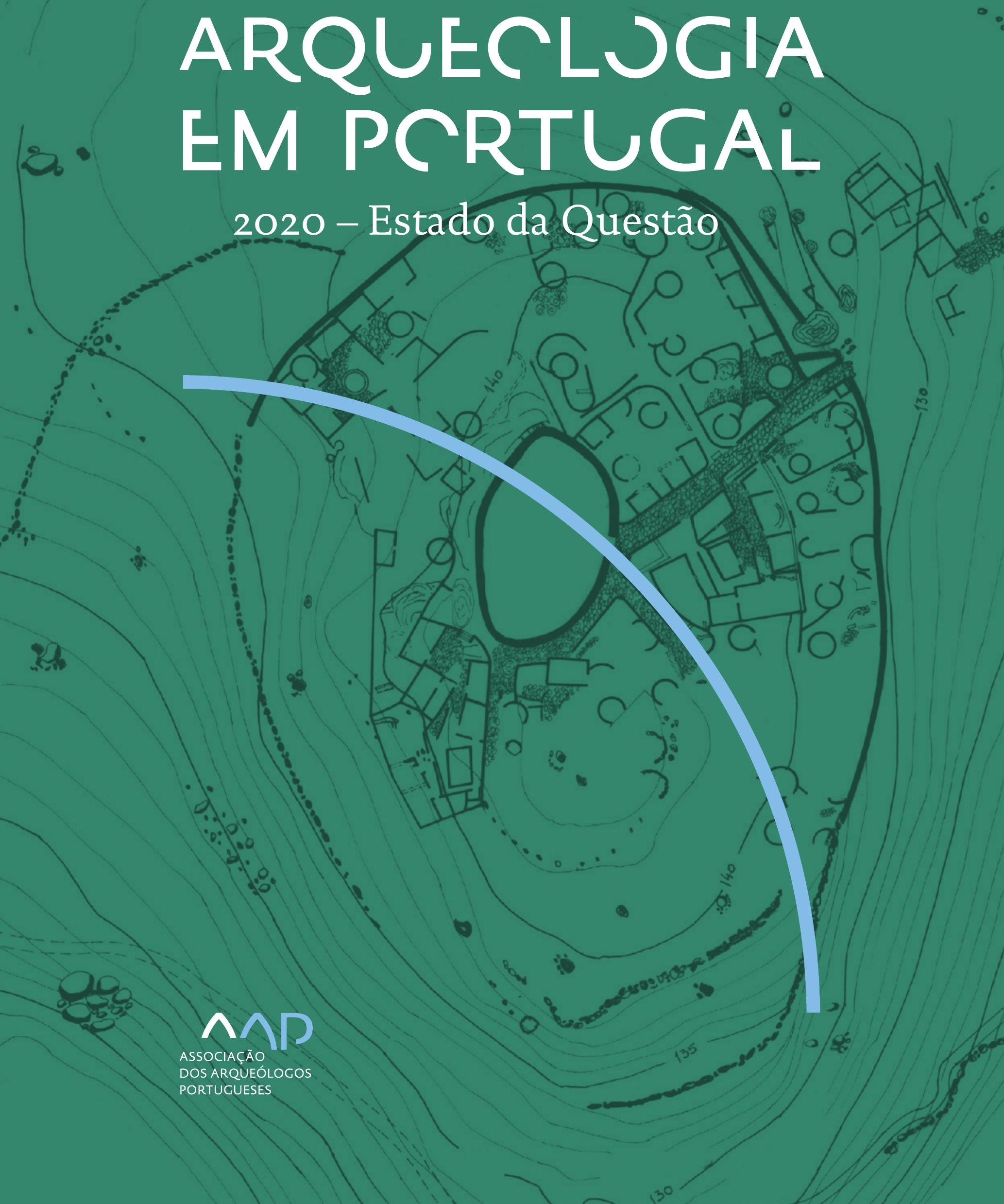


Coordenação editorial: José Morais Arnaud, César Neves e Andrea Martins Design gráfico: Flatland Design

AAP - ISBN: 978-972-9451-89-8

CITCEM - ISBN: 978-989-8970-25-1

Associação dos Arqueólogos Portugueses e CITCEM

Lisboa, 2020

O conteúdo dos artigos é da inteira responsabilidade dos autores. Sendo assim a Associação dos Arqueólogos Portugueses declina qualquer responsabilidade por eventuais equívocos ou questões de ordem ética e legal.

Desenho de capa:

Planta do castro de Monte Mozinho (Museu Municipal de Penafiel).

\section{$\hat{\wedge} \mathrm{P}$}

DOS ARQUEÓLOGOS PORTUGUESES

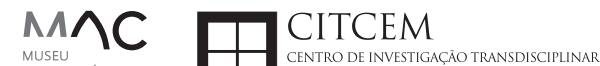
MUSEU
ARQUELLÓGICO
DO CARMO
U.PORTO

FLUP FACULDADE DE LETRAS
UNIVERSIDADE DO PORTO

Apoio

EC para a Ciência 


\section{Índice}

15 Prefácio

José Morais Arnaud

\section{Historiografia e Teoria}

17 Território, comunidade, memória e emoção: a contribuição da história da arqueologia (algumas primeiras e breves reflexões)

Ana Cristina Martins

25 Como descolonizar a arqueologia portuguesa?

Rui Gomes Coelho

41 Arqueologia e Modernidade: uma revisitação pessoal e breve de alguns aspetos da obra homónima de Julian Thomas de 2004

Vítor Oliveira Jorge

57 Dados para a História das Mulheres na Arqueologia portuguesa, dos finais do século XIX aos inícios do século XX: números, nomes e tabelas

Filipa Dimas / Mariana Diniz

73 Retractos da arqueologia portuguesa na imprensa: (in)visibilidades no feminino

Catarina Costeira / Elsa Luís

85 Arqueologia e Arqueólogos no Norte de Portugal Jacinta Bugalhão

101 Vieira Guimarães (1864-1939) e a arqueologia em Tomar: uma abordagem sobre o território e as gentes

João Amendoeira Peixoto / Ana Cristina Martins

115 Os memoráveis? A arqueologia algarvia na imprensa nacional e regional na presente centúria (2001-2019): características, visões do(s) passado(s) e a arqueologia

enquanto marca

Frederico Agosto / João Silva

129 A Evolução da Arqueologia Urbana e a Valorização Patrimonial no Barlavento Algarvio: Os casos de Portimão e Silves

Artur Mateus / Diogo Varandas / Rafael Boavida

\section{Gestão, Valorização e Salvaguarda do Património}

145 O Caderno Reivindicativo e as condições de trabalho em Arqueologia Miguel Rocha / Liliana Matias Carvalho / Regis Barbosa / Mauro Correia / Sara Simões / Jacinta Bugalhão / Sara Brito / Liliana Veríssimo Carvalho / Richard Peace / Pedro Peça / Cézer Santos

155 Os Estudos de Impacte Patrimonial como elemento para uma estratégia sustentável de minimização de impactes no âmbito de reconversões agrícolas Tiago do Pereiro

165 Salvaguarda de Património arqueológico em operações florestais: gestão e sensibilização Filipa Bragança / Gertrudes Zambujo / Sandra Lourenço / Belém Paiva / Carlos Banha / Frederico Tatá Regala / Helena Moura / Jacinta Bugalhão / João Marques / José Correia / Pedro Faria / Samuel Melro

179 Os valores do Património: uma investigação sobre os Sítios Pré-históricos de Arte Rupestre do Vale do Rio Côa e de Siega Verde José Paulo Francisco 
189 Conjugando recursos arqueológicos e naturais para potenciar as visitas ao Geoparque Litoral de Viana do Castelo (Noroeste de Portugal)

Hugo A. Sampaio / Ana M.S. Bettencourt / Susana Marinho / Ricardo Carvalhido

203 Áreas de Potencial Arqueológico na Região do Médio Tejo: Modelo Espacial Preditivo Rita Ferreira Anastácio / Ana Filipa Martins / Luiz Oosterbeek

223 Património Arqueológico e Gestão Territorial: O contributo da Arqueologia para a revisão do PDM de Avis

Ana Cristina Ribeiro

237 A coleção arqueológica do extinto Museu Municipal do Porto - Origens, Percursos e Estudos

Sónia Couto

251 Valpaços - uma nova carta arqueológica

Pedro Pereira / Maria de Fátima Casares Machado

263 Arqueologia na Cidade de Peniche

Adriano Constantino / Luís Rendeiro

273 Arqueologia Urbana: a cidade de Lagos como caso de Estudo Cátia Neto

285 Estratégias de promoção do património cultural subaquático nos Açores. O caso da ilha do Faial

José Luís Neto / José Bettencourt / Luís Borges / Pedro Parreira

297 Carta Arqueológica da Cidade Velha: Uma primeira abordagem

Jaylson Monteiro / Nireide Tavares / Sara da Veiga / Claudino Ramos / Edson Brito /

Carlos Carvalho / Francisco Moreira / Adalberto Tavares

311 Antropologia Virtual: novas metodologias para a análise morfológica e funcional Ricardo Miguel Godinho / Célia Gonçalves

\section{Didáctica da Arqueologia}

327 Como os projetos de Arqueologia podem contribuir para uma comunidade culturalmente mais consciente Alexandra Figueiredo / Claúdio Monteiro / Adolfo Silveira / Ricardo Lopes

337 Educação Patrimonial - Um cidadão esclarecido é um cidadão ativo! Ana Paula Almeida

351 A aproximação da Arqueologia à sala de aula: um caso de estudo no $3^{\circ}$ ciclo do Ensino Básico Luís Serrão Gil

363 Arqueologia 3.o - Pensar e comunicar a Arqueologia para um futuro sustentável Mónica Rolo

377 “Conversa de Arqueólogos" - Divulgar a Arqueologia em tempos de Pandemia Diogo Teixeira Dias

389 Escola Profissional de Arqueologia: desafios e oportunidades Susana Nunes / Dulcineia Pinto / Júlia Silva / Ana Mascarenhas

399 Os Museus de Arqueologia e os Jovens: a oferta educativa para o público adolescente Beatriz Correia Barata / Leonor Medeiros

411 O museu universitário como mediador entre a ciência e a sociedade: o exemplo da secção de arqueologia no Museu de História Natural e da Ciência da Universidade do Porto (MHNC-UP)

Rita Gaspar 
421 Museu de Lanifícios: Real Fábrica de Panos. Atividades no âmbito da Arqueologia Beatriz Correia Barata / Rita Salvado

427 Arqueologia Pública e o caso da localidade da Mata (Torres Novas) Cláudia Manso / Ana Rita Ferreira / Cristiana Ferreira / Vanessa Cardoso Antunes

431 Do sítio arqueológico ao museu: um percurso (também) didático Lídia Fernandes

447 Estão todos convidados para a Festa! E para dançar também... O projecto do Serviço Educativo do Museu Arqueológico do Carmo na $5^{\underline{a}}$ Edição da Festa da Arqueologia Rita Pires dos Santos

459 O “Clã de Carenque”, um projeto didático de arqueologia Eduardo Gonzalez Rocha

469 Mediação cultural: peixe que puxa carroça nas Ruínas Romanas de Troia Inês Vaz Pinto / Ana Patrícia Magalhães / Patrícia Brum / Filipa Santos

481 Didática Arqueológica, experiências do Projeto Mértola Vila Museu Maria de Fátima Palma / Clara Rodrigues / Susana Gómez / Lígia Rafael

\section{Arte Rupestre}

497 Os inventários de arte rupestre em Portugal Mila Simões de Abreu

513 O projeto FIRST-ART - conservação, documentação e gestão das primeiras manifestações de arte rupestre no Sudoeste da Península Ibérica: as grutas do Escoural e Maltravieso Sara Garcês / Hipólito Collado / José Julio García Arranz / Luiz Oosterbeek / António Carlos Silva / Pierluigi Rosina / Hugo Gomes / Anabela Borralheiro Pereira / George Nash / Esmeralda Gomes / Nelson Almeida / Carlos Carpetudo

523 Trabalhos de documentação de arte paleolítica realizados no âmbito do projeto PalæoCôa André Tomás Santos / António Fernando Barbosa / Luís Luís / Marcelo Silvestre / Thierry Aubry

537 Imagens fantasmagóricas, silhuetas elusivas: as figuras humanas na arte do Paleolítico Superior da região do Côa Mário Reis

$55^{1}$ Os motivos zoomórficos representados nas placas de tear de Vila Nova de São Pedro (Azambuja, Portugal) Andrea Martins / César Neves / José M. Arnaud / Mariana Diniz

571 Arte Rupestre do Monte de Góios (Lanhelas, Caminha). Síntese dos resultados dos trabalhos efectuados em 2007-2009 Mário Varela Gomes

599 Gravuras rupestres de barquiformes no Monte de S. Romão, Guimarães, Noroeste de Portugal Daniela Cardoso

613 Círculos segmentados gravados na Bacia do Rio Lima (Noroeste de Portugal): contributos para o seu estudo Diogo Marinho / Ana M.S. Bettencourt / Hugo Aluai Sampaio

631 Equídeos gravados no curso inferior do Rio Mouro, Monção (NW Portugal). Análise preliminar Coutinho, L.M. / Bettencourt, A.M.S / Sampaio, Hugo A.S

645 Paletas na Arte Rupestre do Noroeste de Portugal. Inventário preliminar Bruna Sousa Afonso / Ana M. S. Bettencourt / Hugo A. Sampaio 


\section{Pré-História}

661 O projeto Miño/Minho: balanço de quatro anos de trabalhos arqueológicos Sérgio Monteiro-Rodrigues / João Pedro Cunha-Ribeiro / Eduardo Méndez-Quintas / Carlos Ferreira / Pedro Xavier / José Meireles / Alberto Gomes / Manuel Santonja / Alfredo Pérez-González

677 A ocupação paleolítica da margem esquerda do Baixo Minho: a indústria lítica do sítio de Pedreiras 2 (Monção, Portugal) e a sua integração no contexto regional Carlos Ferreira / João Pedro Cunha-Ribeiro / Sérgio Monteiro-Rodrigues / Eduardo Méndez-Quintas / Pedro Xavier / José Meireles / Alberto Gomes / Manuel Santonja / Alfredo Pérez-González

693 O sítio acheulense do Plistocénico médio da Gruta da Aroeira Joan Daura / Montserrat Sanz / Filipa Rodrigues / Pedro Souto / João Zilhão

703 As sociedades neandertais no Barlavento algarvio: modelos preditivos com recurso aos SIG

Daniela Maio

715 A utilização de quartzo durante o Paleolítico Superior no território dos vales dos rios Vouga e Côa

Cristina Gameiro / Thierry Aubry / Bárbara Costa / Sérgio Gomes / Luís Luís / Carmen Manzano / André Tomás Santos

733 Uma perspetiva diacrónica da ocupação do concheiro do Cabeço da Amoreira (Muge, Portugal) a partir da tecnologia lítica Joana Belmiro / João Cascalheira / Célia Gonçalves

745 Novos dados sobre a Pré-história Antiga no concelho de Palmela. A intervenção arqueológica no sítio do Poceirão I

Michelle Teixeira Santos

757 Problemas em torno de Datas Absolutas Pré-Históricas no Norte do Alentejo Jorge de Oliveira

771 Povoamento pré-histórico nas áreas montanhosas do NO de Portugal: o Abrigo 1 de Vale de Cerdeira Pedro Xavier / José Meireles / Carlos Alves

783 Apreciação do povoamento do Neolítico Inicial na Baixa Bacia do Douro. A Lavra I (Serra da Aboboreira) como caso de estudo Maria de Jesus Sanches

797 O Processo de Neolitização na Plataforma do Mondego: os dados do Sector C do Outeiro dos Castelos de Beijós (Carregal do Sal)

João Carlos de Senna-Martinez / José Manuel Quintã Ventura / Andreia Carvalho / Cíntia Maurício

823 Novos trabalhos na Lapa da Bugalheira (Almonda, Torres Novas) Filipa Rodrigues / Pedro Souto / Artur Ferreira / Alexandre Varanda / Luís Gomes / Helena Gomes / João Zilhão

837 A pedra polida e afeiçoada do sítio do Neolítico médio da Moita do Ourives (Benavente, Portugal)

César Neves

857 Casal do Outeiro (Encarnação, Mafra): novos contributos para o conhecimento do povoamento do Neolítico final na Península de Lisboa.

Cátia Delicado / Carlos Maneira e Costa / Marta Miranda / Ana Catarina Sousa

873 Stresse infantil, morbilidade e mortalidade no sítio arqueológico do Neolítico Final/ Calcolítico ( $4^{\circ}$ e $3^{\circ}$ milénio a.C.) do Monte do Carrascal 2 (Ferreira do Alentejo, Beja) Liliana Matias de Carvalho / Sofia N. Wasterlain 
885 Come together: O Conjunto Megalítico das Motas (Monção, Viana do Castelo) e as expressões Campaniformes do Alto Minho Ana Catarina Basílio / Rui Ramos

899 Trabalhos arqueológicos no sítio Calcolítico da Pedreira do Poio Carla Magalhães / João Muralha / Mário Reis / António Batarda Fernandes

913 O sítio arqueológico de Castanheiro do Vento. Da arquitectura do sítio à arquitectura de um território João Muralha Cardoso

925 Estudo zooarqueológico das faunas do Calcolítico final de Vila Nova de São Pedro (Azambuja, Portugal): Campanhas de 2017 e 2018 Cleia Detry / Ana Catarina Francisco / Mariana Diniz / Andrea Martins / César Neves / José Morais Arnaud

943 As faunas depositadas no Museu Arqueológico do Carmo provenientes de Vila Nova de São Pedro (Azambuja): as campanhas de 1937 a 1967 Ana Catarina Francisco / Cleia Detry / César Neves / Andrea Martins / Mariana Diniz / José Morais Arnaud

959 Análise funcional de material lítico em sílex do castro de Vila Nova de S. Pedro (Azambuja, Portugal): uma primeira abordagem Rafael Lima

971 O recinto da Folha do Ouro 1 (Serpa) no contexto dos recintos de fossos calcolíticos alentejanos

António Carlos Valera / Tiago do Pereiro / Pedro Valério / António M. Monge Soares

\section{Proto-História}

987 Produção de sal marinho na Idade do Bronze do noroeste Português. Alguns dados para uma reflexão

Ana M. S. Bettencourt / Sara Luz / Nuno Oliveira / Pedro P. Simões / Maria Isabel C. Alves / Emílio Abad-Vidal

1001 A estátua-menir do Pedrão ou de São Bartolomeu do Mar (Esposende, noroeste de Portugal) no contexto arqueológico da fachada costeira de entre os rios Neiva e Cávado Ana M. S. Bettencourt / Manuel Santos-Estévez / Pedro Pimenta Simões / Luís Gonçalves

1015 O Castro do Muro (Vandoma/Baltar, Paredes) - notas para uma biografia de ocupação da Idade do Bronze à Idade Média

Maria Antónia D. Silva / Ana M. S. Bettencourt / António Manuel S. P. Silva / Natália Félix

1031 Do Bronze Final à Idade Média - continuidades e hiatos na ocupação de Povoados em Oliveira de Azeméis João Tiago Tavares / Adriaan de Man

1041 As faunas do final da Idade do Bronze no Sul de Portugal: leituras desde o Outeiro do Circo (Beja)

Nelson J. Almeida / Íris Dias / Cleia Detry / Eduardo Porfírio / Miguel Serra

1055 A Espada do Monte das Oliveiras (Serpa) - uma arma do Bronze Pleno do Sudoeste Rui M. G. Monge Soares / Pedro Valério / Mariana Nabais / António M. Monge Soares

1065 São Julião da Branca (Albergaria-a-Velha) - Investigação e valorização de um povoado do Bronze Final

António Manuel S. P. Silva / Paulo A. P. Lemos / Sara Almeida e Silva / Edite Martins de Sá

1083 Do castro de S. João ao Mosteiro de Santa Clara: notícia de uma intervenção arqueológica, em Vila do Conde Rui Pinheiro 
1095 O castro de Ovil (Espinho), um quarto de século de investigação - resultados e questões em aberto

Jorge Fernando Salvador / António Manuel S. P. Silva

1111 O Castro de Salreu (Estarreja), um povoado proto-histórico no litoral do Entre Douro e Vouga

Sara Almeida e Silva / António Manuel S. P. Silva / Paulo A. P. Lemos / Edite Martins de Sá

1127 Castro de Nossa Senhora das Necessidades (Sernancelhe): uma primeira análise artefactual Telma Susana O. Ribeiro

${ }_{1141}$ A cividade de Bagunte. O estado atual da investigação Pedro Brochado de Almeida

1153 Zoomorfos na cerâmica da Idade do Ferro no NW Peninsular: inventário, cronologias e significado Nuno Oliveira / Cristina Seoane

1163 Vasos gregos em Portugal: diferentes maneiras de contar a história do intercâmbio cultural na Idade do Ferro

Daniela Ferreira

1175 Os exotica da necrópole da Idade do Ferro do Olival do Senhor dos Mártires (Alcácer do Sal) no seu contexto regional

Francisco B. Gomes

\section{Antiguidade Clássica e Tardia}

1191 O uso de madeira como combustível no sítio da Quinta de Crestelos (Baixo Sabor): da Idade do Ferro à Romanização Filipe Vaz / João Tereso / Sérgio Simões Pereira / José Sastre / Javier Larrazabal Galarza / Susana Cosme / José António Pereira / Israel Espi

1207 Cultivos de Época Romana no Baixo Sabor: continuidade em tempos de mudança? João Pedro Tereso / Sérgio Simões Pereira / Filipe Santos / Luís Seabra / Filipe Vaz

1221 A casa romana na Hispânia: aplicação dos modelos itálicos nas províncias ibéricas Fernanda Magalhães / Diego Machado / Manuela Martins

1235 As pinturas murais romanas da Rua General Sousa Machado, n. ${ }^{5}$ 1, Chaves José Carvalho

1243 Trás do Castelo (Vale de Mir, Pegarinhos, Alijó) - Uma exploração agrícola romana do Douro

Tony Silvino / Pedro Pereira

1255 A sequência de ocupação no quadrante sudeste de Bracara Augusta: as transformações de uma unidade doméstica Lara Fernandes / Manuela Martins

1263 Os Mosaicos com decoração geométrica e geométrico-vegetalista dos sítios arqueológicos da área do Conuentus Bracaraugustanus. Novas abordagens quanto à conservação, restauro, decoração e datação Maria de Fátima Abraços / Licínia Wrench

1277 “Casa Romana” do Castro de São Domingos (Cristelos, Lousada): Escavação, Estudo e Musealização Paulo André de P. Lemos

1291 A arqueobotânica no Castro de Guifões (Matosinhos, Noroeste de Portugal): O primeiro estudo carpológico

Luís Seabra / Andreia Arezes / Catarina Magalhães / José Varela / João Pedro Tereso 
1305 Um Horreum Augustano na Foz do Douro (Monte do Castelo de Gaia, Vila Nova de Gaia) Rui Ramos

1311 Ponderais romanos na Lusitânia: padrões, formas, materiais e contextos de utilização Diego Barrios Rodríguez

1323 Um almofariz centro-itálico na foz do Mondego

Marco Penajoia

1335 Estruturas romanas de Carnide - Lisboa Luísa Batalha / Mário Monteiro / Guilherme Cardoso

1347 O contexto funerário do sector da "necrópole NO" da Rua das Portas de S. Antão (Lisboa): o espaço, os artefactos, os indivíduos e a sua interconectividade na interpretação do passado Sílvia Loja, José Carlos Quaresma, Nelson Cabaço, Marina Lourenço, Sílvia Casimiro, Rodrigo Banha da Silva, Francisca Alves-Cardoso

${ }_{1361}$ Povoamento em época Romana na Amadora - resultados de um projeto pluridisciplinar Gisela Encarnação / Vanessa Dias

1371 A Arquitectura Residencial em Mirobriga (Santiago do Cacém): contributo a partir de um estudo de caso Filipe Sousa / Catarina Felício

${ }_{1385}$ O fim do ciclo. Saneamento e gestão de resíduos nos edifícios termais de Mirobriga (Santiago do Cacém)

Catarina Felício / Filipe Sousa

1399 Balsa, Topografia e Urbanismo de uma Cidade Portuária Vítor Silva Dias / João Pedro Bernardes / Celso Candeias / Cristina Tété Garcia

1413 No Largo das Mouras Velhas em Faro (2017): novas evidências da necrópole norte de Ossonoba e da sua ocupação medieval Ricardo Costeira da Silva / Paulo Botelho / Fernando Santos / Liliana Nunes

1429 Instrumentos de pesca recuperados numa fábrica de salga em Ossonoba (Faro) Inês Rasteiro / Ricardo Costeira da Silva / Paulo Botelho

1439 A Necrópole Romana do Eirô, Duas Igrejas (Penafiel): intervenção arqueológica de 2016 Laura Sousa / Teresa Soeiro

1457 Ritual, descarte ou afetividade? A presença de Canis lupus familiaris na Necrópole Noroeste de Olisipo (Lisboa)

Beatriz Calapez Santos / Sofia Simões Pereira / Rodrigo Banha da Silva / Sílvia Casimiro / Cleia Detry / Francisca Alves Cardoso

1467 Dinâmicas económicas em Bracara na Antiguidade Tardia Diego Machado / Manuela Martins / Fernanda Magalhães / Natália Botica

1479 Cerâmicas e Vidros da Antiguidade Tardia do Edifício sob a Igreja do Bom Jesus (Vila Nova de Gaia) Joaquim Filipe Ramos

1493 Novos contributos para a topografia histórica de Mértola no período romano e na Antiguidade Tardia Virgílio Lopes

\section{8. Época Medieval}

1511 Cerâmicas islâmicas no Garb setentrional "português": algumas evidências e incógnitas Constança dos Santos / Helena Catarino / Susana Gómez / Maria José Gonçalves / Isabel Inácio / Gonçalo Lopes / Jacinta Bugalhão / Sandra Cavaco / Jaquelina Covaneiro / Isabel Cristina Fernandes / Ana Sofia Gomes 
1525 Contributo para o conhecimento da cosmética islâmica, em Silves, durante a Idade Média Rosa Varela Gomes

1537 Yábura e o seu território - uma análise histórico-arqueológica de Évora entre os séculos VIII-XII José Rui Santos

1547 A encosta sul do Castelo de Palmela - resultados preliminares da escavação arqueológica Luís Filipe Pereira / Michelle Teixeira Santos

1559 A igreja de São Lourenço (Mouraria, Lisboa): um conjunto de silos e de cerâmica medieval islâmica

Andreia Filipa Moreira Rodrigues

1571 O registo material de movimentações populacionais no Médio Tejo, durante os séculos XII-XIII. Dois casos de "sunken featured buildings", nos concelhos de Cartaxo e Torres Novas Marco Liberato / Helena Santos / Nuno Santos

1585 O nordeste transmontano nos alvores da Idade média. Notas para reflexão Ana Maria da Costa Oliveira

1601 Sepulturas escavadas na rocha do Norte de Portugal e do Vale do Douro: primeiros resultados do Projecto SER-NPVD

Mário Jorge Barroca / César Guedes / Andreia Arezes / Ana Maria Oliveira

1619 "Portucalem Castrum Novum" entre o Mediterrâneo e o Atlântico: o estudo dos materiais cerâmicos alto-medievais do arqueossítio da rua de D. Hugo, nํ. 5 (Porto) João Luís Veloso

1627 A Alta Idade Média na fronteira de Lafões: notas preliminares sobre a Arqueologia no Concelho de Vouzela

Manuel Luís Real / Catarina Tente

1641 Um conjunto cerâmico medieval fora de portas: um breve testemunho aveirense Susana Temudo

${ }_{1651}$ Os Lóios do Porto: uma perspetiva integrada no panorama funerário da Baixa Idade Média à Época Moderna em meios urbanos em Portugal

Ana Lema Seabra

1659 O Caminho Português Interior de Santiago como eixo viário na Idade Média Pedro Azevedo

1665 Morfologia Urbana: Um exercício em torno do Castelo de Ourém André Donas-Botto / Jaqueline Pereira

1677 Intervenção arqueológica na Rua Marquês de Pombal/Largo do Espírito Santo (Bucelas, Loures)

Florbela Estêvão / Nathalie Antunes-Ferreira / Dário Ramos Neves / Inês Lisboa

1691 O Cemitério Medieval do Poço do Borratém e a espacialidade funerária na cidade de Lisboa Inês Belém / Vanessa Filipe / Vasco Noronha Vieira / Sónia Ferro / Rodrigo Banha da Silva

1705 Um Espaço Funerário Conventual do séc. XV em Lisboa: o caso do Convento de São Domingos da Cidade Sérgio Pedroso / Sílvia Casimiro / Rodrigo Banha da Silva / Francisca Alves Cardoso

\section{9. Época Moderna e Contemporânea}

1721 Arqueologia Moderna em Portugal: algumas reflexões críticas em torno da quantificação de conjuntos cerâmicos e suas inferências históricas e antropológicas Rodrigo Banha da Silva / André Bargão / Sara da Cruz Ferreira

1733 Faianças de dois contextos entre os finais do século XVI e XVIII do Palácio dos Condes de Penafiel, Lisboa

Martim Lopes / Tomás Mesquita 
1747 Um perfil de consumo do século XVIII na foz do Tejo: O caso do Mercado da Ribeira, Lisboa Sara da Cruz Ferreira / Rodrigo Banha da Silva / André Bargão

1761 Os Cachimbos dos Séculos XVII e XVIII do Palácio Mesquitela e Convento dos Inglesinhos (Lisboa)

Inês Simão / Marina Pinto / João Pimenta / Sara da Cruz Ferreira / André Bargão / Rodrigo Banha da Silva

1775 "Tomar os fumos da erua que chamão em Portugal erua sancta». Estudo de Cachimbos provenientes da Rua do Terreiro do Trigo, Lisboa

Miguel Martins de Sousa / José Pedro Henriques / Vanessa Galiza Filipe

1787 Cachimbos de Barro Caulínitico da Sé da Cidade Velha (República de Cabo Verde)

Rodrigo Banha da Silva / João Pimenta / Clementino Amaro

1801 Algumas considerações sobre espólio não cerâmico recuperado no Largo de Jesus (Lisboa) Carlos Boavida

1815 Adereços de vidro, dos séculos XVI-XVIII, procedentes do antigo Convento de Santana de Lisboa (anéis, braceletes e contas)

Joana Gonçalves / Rosa Varela Gomes / Mário Varela Gomes

1837 Da ostentação, luxo e poder à simplicidade do uso quotidiano: arqueologia e simbologia de joias e adornos da Idade Moderna Portuguesa Jéssica Iglésias

1849 Os amuletos em Portugal - dos objetos às superstições: o coral vermelho Alexandra Vieira

1865 Cerâmicas de Vila Franca de Xira nos séculos XV e XVI Eva Pires

1879 «Não passa por teu o que me pertence». Marcas de individualização associadas a faianças do Convento de Nossa Senhora de Aracoeli, Alcácer do Sal Catarina Parreira / Íris Fragoso / Miguel Martins de Sousa

1891 Cerâmica de Leiria: alguns focos de produção

Jaqueline Pereira / André Donas-Botto

1901 Os Fornos na Rua da Biquinha, em Óbidos Hugo Silva / Filipe Oliveira

1909 A casa de Pêro Fernandes, contador dos contos de D. Manuel I: o sítio arqueológico da Silha do Alferes, Seixal (século XVI) Mariana Nunes Ferreira

1921 O Alto da Vigia (Sintra) e a vigilância e defesa da costa Alexandre Gonçalves / Sandra Santos

1937 O contexto da torre sineira da Igreja de Santa Maria de Loures Paulo Calaveira / Martim Lopes

1949 A Necrópole do Hospital Militar do Castelo de São Jorge e as práticas funerárias na Lisboa de Época Moderna Susana Henriques / Liliana Matias de Carvalho / Ana Amarante / Sofia N. Wasterlain

1963 SAND - Sarilhos Grandes Entre dois Mundos: o adro da Igreja e a Paleobiologia dos ossos humanos recuperados

Paula Alves Pereira / Roger Lee Jesus / Bruno M. Magalhães

1975 Expansão urbana da vila de Cascais no século XVII e XVIII: a intervenção arqueológica na Rua da Vitória no 15 a 17

Tiago Pereira / Vanessa Filipe

1987 Novos dados para o conhecimento do Urbanismo de Faro em época Moderna Ana Rosa 
1995 Um exemplo de Arqueologia Urbana em Alcoutim: o Antigo Edifício dos CTT Marco Fernandes / Marta Dias / Alexandra Gradim / Virgílio Lopes / Susana Gómez Martínez

2007 Palácio dos Ferrazes (Rua das Flores/Rua da Vitória, Porto): a cocheira de Domingos Oliveira Maia

Francisco Raimundo

2021 As muitas vidas de um edifício urbano: História, Arqueologia e Antropologia no antigo Recreatório Paroquial de Penafiel Helena Bernardo / Jorge Sampaio / Marta Borges

2035 O convento de Nossa Senhora da Esperança de Ponta Delgada: o contributo da arqueologia para o conhecimento de um monumento identitário João Gonçalves Araújo / N’Zinga Oliveira

2047 Arqueologia na ilha do Corvo... em busca da capela de Nossa Senhora do Rosário Tânia Manuel Casimiro / José Luís Neto / Luís Borges / Pedro Parreira

2059 Perdidos à vista da Costa. Trabalhos arqueológicos subaquáticos na Barra do Tejo Jorge Freire / José Bettencourt / Augusto Salgado

2071 Arqueologia marítima em Cabo Verde: enquadramento e primeiros resultados do projecto CONCHA

José Bettencourt / Adilson Dias / Carlos Lima / Christelle Chouzenoux / Cristóvão Fonseca / Dúnia Pereira / Gonçalo Lopes / Inês Coelho / Jaylson Monteiro / José Lima / Maria Eugénia Alves / Patrícia Carvalho / Tiago Silva

2085 Trabalhos arqueológicos na Cidade Velha (Ribeira Grande de Santiago, Cabo Verde): reflexões sobre um projecto de investigação e divulgação patrimonial André Teixeira / Jaylson Monteiro / Mariana Mateus / Nireide Tavares / Cristovão Fonseca / Gonçalo C. Lopes / Joana Bento Torres / Dúnia Pereira / André Bargão / Aurélie Mayer / Bruno Zélie / Carlos Lima / Christelle Chouzenoux / Inês Henriques / Inês Pinto Coelho / José Lima / Patrícia Carvalho / Tiago Silva

2103 A antiga fortificação de Quelba / Khor Kalba (E.A.U.). Resultados de quatro campanhas de escavações, problemáticas e perspectivas futuras Rui Carita / Rosa Varela Gomes / Mário Varela Gomes / Kamyar Kamyad

2123 Colónias para homens novos: arqueologia da colonização agrária fascista no noroeste ibérico Xurxo Ayán Vila / José Mạ . Señorán Martín 


\title{
“CONVERSA DE ARQUEÓLOGOS”- DIVULGAR A ARQUEOLOGIA EM TEMPOS DE PANDEMIA
}

Diogo Teixeira Dias ${ }^{1}$

\begin{abstract}
RESUMO
As “Conversas de Arqueólogos" foram eventos informais de divulgação da Arqueologia em Portugal, realizadas em streaming, em direto, a partir dos Açores, nos meses de maio e junho de 2020, e promovidas pela Fundação Manuel Sousa de Oliveira, com sede em Ponta Delgada, orientada para a promoção da Arqueologia nos Açores. A iniciativa à distância tornou-se uma solução alternativa aos habituais "Clubes de História”, que a Fundação organizava desde 2018, mas que por razão do confinamento obrigatório, provocado pela pandemia Covid-19, foram suspensas.

Este artigo patenteia sumariamente a atividade da Fundação, do seu fundador e expõe os objetivos das "Conversas de Arqueólogos”, a sua metodologia e os seus resultados, em prol da divulgação e acessibilidade digital do Património Arqueológico e do seu processo científico.

Palavras-chave: Arqueologia, Açores, Divulgação, Streaming, Acessibilidade.
\end{abstract}

\begin{abstract}
The "Conversas de Arqueólogos" were informal events for Archaeology dissemination in Portugal, held live stream, broadcasted from the Azores Islands, in May and June 2020, and promoted by the Manuel Sousa de Oliveira Foundation, based in Ponta Delgada, oriented to the promotion of Archaeology in the Azores.

The online initiative has become an alternative solution to the usual "Clubes de História", which the Foundation organized since 2018, but which, because of the mandatory confinement caused by the Covid-19 pandemic, have been suspended.

This article summarily patents the activity of the Foundation, its founder's life and shows the aims of the "Conversas de Arqueólogos", its methods and its results, in favor of the dissemination and digital accessibility of the Archaeological Heritage and its scientific process.
\end{abstract}

Keywords: Archaeology, Azores, Sharing, Streaming, Accessibility.

\section{ENQUADRAMENTO}

Desde o início do ano de 2020 que o mundo inteiro foi obrigado a reestruturar o seu quotidiano, em todas as suas dimensões. A cultura e a ciência não foram exceção.

Assistiu-se à proliferação de várias iniciativas em streaming que, de alguma forma, permitiram a aproximação de dimensões em que, outrora, a distância física se constituía como impedimento, não obstante da tecnologia atualmente ao dispor.

O confinamento inerente à pandemia Covid-19 constituiu-se numa oportunidade não tanto de re- pensar formas de contacto com o público, mas de as aplicar de modo mais sistemático e recorrente.

Com isso, permaneceram e permanecem largamente beneficiados todos os públicos, mas particularmente os residentes nas zonas ultra-periféricas da Europa, como é o caso dos Açores.

Em maio deste ano, a Fundação Sousa de Oliveira, sediada em Ponta Delgada, homónima do pioneiro da Arqueologia nos Açores, promoveu um encontro público, disseminado em direto para a rede social Facebook, de forma gratuita, e em disponibilização permanente, designado "Conversa de Arqueólogos". Augura-se apresentar o conceito e a experiência da

1. (AAP/CMVFC) 
iniciativa, os objetivos a que se propôs, a metodologia que os permitiu atingir e os resultados alcançados, de forma eficaz e eficiente.

Dado o carácter recente da criação da entidade promotora do evento, irá proceder-se a uma introdução com uma digressão pela história da instituição e a vida do arqueólogo homónimo.

\section{MANUEL SOUSA DE OLIVEIRA}

Manuel Sousa de Oliveira, o "pioneiro da Arqueologia nos Açores” (BENTO, 1990; NETO, 2018), nasceu a 18 de julho de 1916, em Cambridge (Massachussets, E.U.A.), filho de emigrantes açorianos, que regressaram precocemente à Ilha de S. Miguel (BAIROS, 2018; BENTO, 1990). Realizou praticamente todo o seu percurso escolar nos Açores, tendo-se licenciado em Ciências Históricas e Filosóficas, na Universidade de Coimbra (25 de julho de 1942). Na cidade universitária, que o próprio assume como tendo sido a mais marcante da sua vida (Figura 1), pratica com mérito uma série de modalidades desportivas, inclusive futebol, na Associação Académica de Coimbra² . Interrompe a vida académica para cumprir serviço militar. Entre 1947 e 1951, dedica-se ao ensino particular em quatro colégios. Nos anos 50 , inicia a sua carreira na função pública, como Diretor do Museu Regional de Viana do Castelo, conhecendo, trabalhando e publicando com Abel Viana (VIANA e OLIVEIRA, 1954), que o inicia na Arqueologia (Figura 2). Nos anos 6o, leciona no Liceu Nacional de Aveiro e na Escola Industrial e Comercial Avelar Brotero (Coimbra), e nos finais da década é bolseiro da Gulbenkian, para a recolha do Teatro Popular nos Açores (BAIROS, 2018). Em 1971, que funda o "Clube de História" - uma associação com orientação para o estudo e divulgação da Arqueologia e Etnografia de Caldas da Rainha, onde lecionava na altura (BAIROS, 2018; BENTO, 1990).

Entre 1967 e 1982 dirigiu várias intervenções arqueológicas no concelho de Vila Franca do Campo, tendo inaugurado a "segunda fase" da Arqueologia nos Açores, que se estenderá até ao ano de 2004 (NETO, 2018). Os resultados foram extensos e diversos em

\footnotetext{
2. Manuel Sousa de Oliveira era conhecido como o "estudante de Oxford" não por ter estudado em Oxford mas devido às suas semelhanças com o ator Robert Taylor e o papel por este assumido no filme de Jack Conway A Yank at Oxford, de 1938 (BAIROS, 2018).
}

termos materiais, tendo sido produzidos cadernos de campo (chamados “diários de escavação"), nunca estudados na sua dimensão de conjunto.

Das campanhas em Vila Franca do Campo, os materiais foram exumados, os diários escritos, mas o conhecimento ficou por produzir e publicar. Em 2018, por nossa proposta, foram entregues à Câmara Municipal de Vila Franca do Campo os diários, em formato digital, para efeitos de estudo e investigação. Perspetiva-se a sua publicação integral, anotada e comentada.

A 24 de agosto de 1985, com os recursos da época, promove a primeira iniciativa de Didática da Arqueologia nos Açores ${ }^{3}$, direcionada a crianças, com recurso a puzzles e kits de simulação de montagem de peças cerâmicas, no Campo de São Francisco, em Ponta Delgada, tendo captado o interesse e recebido a visita do então Presidente do Governo Regional dos Açores, João Bosco Mota Amaral (Figura. 3).

Em 1988, escava no Convento de Jesus, da Ribeira Grande (NETO, 2018), com o apoio de Mário Moura.

\section{SOBRE A FUNDAÇÃO}

Com a morte de Manuel Sousa de Oliveira (4 de agosto de 2001) e por sua disposição testamentária, foi criada a fundação homónima, herdeira de todos os seus bens, onde se depositam, atualmente, parte dos materiais recolhidos em Vila Franca do Campo (BENTO, 1990) ${ }^{4}$.

A Fundação Sousa de Oliveira (Figura 4), instituição de direito privado, e de utilidade pública, tem por fins, conforme disposto nos seus Estatutos, nomeadamente, "promover o fomento dos estudos de arqueologia e trabalhos arqueológicos no arquipélago dos Açores", para além de promover o estudo do espólio em seu depósito, disponibilizando-o aos investigadores interessados (Estatutos FSO, 2004, Art. ${ }^{\circ}$ 2. ${ }^{\circ}$ ).

\footnotetext{
3. Integrada na "Associação Arqueológica do Arquipélago dos Açores", que só é oficialmente criada a 5 de novembro de 2002, já após a morte de Sousa de Oliveira. A Associação existe formalmente mas não apresenta qualquer atividade. Os membros dos seus órgãos sociais são, à data, alguns dos membros da Fundação Sousa de Oliveira.

4. Estes materiais foram inventariados e acondicionados em 2019, com o apoio do Gabinete de Arqueologia e História da Câmara Municipal de Vila Franca do Campo, estando a ser diligenciada, por parte da autarquia, a proposta da sua entrega ao Museu Municipal.
} 
Para além disso, e em estreita colaboração com as autarquias locais dos Açores, com as quais tem realizado protocolos de colaboração, "promover conferências, seminários e exposições, ou outras iniciativas similares." (Estatutos FSO, 2004, Art.. 3.o.).

A Fundação Sousa de Oliveira dinamizou, desde a sua criação recente, várias iniciativas de cariz cultural, presenciais e pontuais. Por seu incremento, arqueólogos regressam ao diálogo com a comunidade na FSO a 1 de fevereiro de 2018, com N'zinga Oliveira e João Gonçalves Araújo, numa comunicação sobre Manuel Sousa de Oliveira e o impulso da Arqueologia nos Açores. Porém, só a partir de junho desse ano, a instituição cria o seu primeiro evento recorrente, dedicado à divulgação do Património Cultural, recuperando a designação de "Clube de História”, numa homenagem e perspetiva de continuidade do trabalho didático do fundador.

Para Manuel Sousa de Oliveira, a divulgação dos resultados da Arqueologia ao público em geral, através da comunicação social, e em iniciativas expositivas, numa linguagem acessível, era tão fundamental como o processo científico em si (BAIROS, 2018; BENTO, 1990).

\section{OS "CLUBES DE HISTÓRIA"}

De frequência mensal, e moderados geralmente pelo Presidente do Conselho de Administração da Fundação Sousa de Oliveira, Carlos Melo Bento, iniciaram-se a 6 de julho de 2018 sobre "Os Açores e a Heráldica".

De referir e destacar, a título de exemplo, o de 7 de janeiro de 2019, sobre "O que foram os Descobrimentos Portugueses?”, com João Paulo Oliveira e Costa; "Os Açores após o 25 de abril", com João Bosco Mota Amaral, a 22 de abril de 2018 e, a 4 de setembro de 2019, assinalando o primeiro aniversário do "Clube de História", "O papel da Arqueologia na defesa do Património Cultural, com N’zinga Oliveira, João Gonçalves Araújo e Diogo Teixeira Dias - os três arqueólogos com atividade na ilha de São Miguel.

Adotou-se nos "Clubes" uma configuração informal do evento, sem recurso a uma mesa que estabelecesse a divisão, ou diferença de cota, entre a audiência e os oradores, que se sentavam em poltronas, orientados diagonalmente, de frente para o público, disposto em fileiras curvas.

Potenciou-se uma adesão presencial constante de cerca de dez a trinta espectadores por evento, ten- do-se feito sempre institucionalmente representar quer o Governo Regional quer a Câmara Municipal de Ponta Delgada e, pontualmente, a Câmara Municipal de Vila Franca do Campo - o que era sintomático quer do interesse para o público, quer do impacto político inerente 5 .

A última sessão, a 30 de janeiro de 2020, contou com um balanço do ano de 2019, pelos jornalistas Paulo Simões (Diretor do Açoriano Oriental) e Emanuel Carreiro (RTP - Açores).

No mês seguinte ao de cada encontro, era publicado o boletim "O Pioneiro", de edição da Fundação, com um resumo do evento, elaborado pelo orador e pela redação. A produção destes elementos só foi possível com o apoio financeiro da Câmara Municipal de Ponta Delgada, integrada numa política de aquisição de publicações de cariz cultural e científico, para distribuição nas escolas do concelho (Diário dos Açores, 16/12/18).

Não se tratou, portanto, analogamente ao que viriam a ser as "Conversas de Arqueólogos", de um fórum científico da História ou da Arqueologia, pese embora tenha contado com a participação de vários investigadores das áreas.

O cerne era a divulgação informada, em envolvente informal.

O resultado alcançado foi, sobretudo, para além da fidelização de um público não académico, que manteve o interesse nas áreas referidas, bem como o contributo para o seu conhecimento das linhas gerais e método de abordagem ao Património Cultural.

\section{AS “CONVERSAS DE ARQUEÓLOGOS” AS IMPOSIÇÕES DO CONFINAMENTO OBRIGATÓRIO}

$\mathrm{O}$ vírus SARS-CoV-2, uma doença respiratória originária em Wuhan, na República Popular da China, classificada como pandemia (Covid-19) pela Organização Mundial de Saúde a 11 de março de 2020, alastrou-se a todo o mundo de forma galopante.

Por conseguinte, impôs-se, pela primeira vez no

5. Destaque-se a importância da realização de convites institucionais para os eventos, por forma a promover uma proximidade profícua entre as instituições e associações de defesa do Património Cultural e os decisores políticos. A formalização de um convite institucional e a presença de uma entidade, mesmo em eventos de cariz informal, implica forçosamente um protocolo, que não deve ser desconhecido dos arqueólogos. 
século, um recolhimento obrigatório à população mundial, decretado pelos estados soberanos, com vista à minoração da sua dispersão.

Em Portugal, o Decreto do Estado de Emergência, declarado pelo Presidente da República previa confinamento ao domicílio e limites muito restritos à circulação de pessoas, a partir das oohoo do dia 19 de março.

Naturalmente, e como é do conhecimento e experiência geral, e que dispensa qualquer referência ou citação, o choque com o quotidiano de todos nós em geral implicou a necessária reversão de prioridades domésticas, sociais, económicas, políticas e não menos culturais ou académicas.

A acessibilidade da Cultura e da Ciência correu o seu maior risco, dadas as afetações não só na procura, como também na oferta. Os agentes culturais e os impulsionadores da ciência encaravam um novo desafio: produzir e chegar ao público.

\section{A PROPOSTA DA FUNDAÇÃO}

Dados os constrangimentos, o "Clube de História" tinha vindo já desde fevereiro a cessar a sua atividade, e em março consuma-se a sua interrupção definitiva, da mesma forma que a grande maioria dos eventos culturais, que promovessem ajuntamentos. Para todos os efeitos, raros seriam os que não se encontravam nessas circunstâncias.

Em abril, recebida a proposta pelo João Figueiredo, Relações Públicas da Fundação Sousa de Oliveira, que sugeriu a conceção e execução de um evento que possibilitasse a divulgação da Arqueologia, mas em formato à distância, avançamos com o projeto. Os recursos eram praticamente nulos.

Ainda assim, propôs-se a realização de um evento em streaming, ou seja, por via de difusão de dados, ao vivo, com recurso à plataforma Zoom, e transmitido em Live Stream, no Facebook da Fundação Sousa de Oliveira ${ }^{6}$.

Não deixe de ser notado que, tempos antes, o Centro de Arqueologia da Universidade de Lisboa (UNIARQ), promovera um conjunto de apresentações similares, recorrendo ao Zoom e através do Youtube, abertas à comunidade, integradas no Seminário de Mestrado da FLUL "Arqueologia e o Mundo Contemporâneo", e que serviram de orientação e modelo para este projeto da Fundação Sousa de Oliveira.

6. https://www.facebook.com/FundacaoSousaDOliveira/

\section{OBJETIVOS}

O objetivo geral foi aproximar os açorianos e açorianas das realidades arqueológicas de todo o país, servindo como plataforma de contacto e, sobretudo, de divulgação do trabalho que se tem concretizado. Os residentes das regiões ultra-periféricas insulares da Europa assistem, muitas vezes, ao condicionamento do acesso a conteúdos culturais que extravasem as suas fronteiras, quanto mais não seja por não haver uma proximidade geográfica com realidades museológicas mais abrangentes que as locais. Em boa verdade, os museus da Região Autónoma dos Açores mantêm, e praticamente em exclusivo, um cariz marcadamente etnográfico, mesmo nas ilhas com um maior Índice de Desenvolvimento (SOUSA, 2009). Assiste-se assim a um certo condicionamento da mundividência dos residentes com interesses culturais, na medida em que, para se imbuírem de outra realidade, mesmo apenas de envergadura nacional, se veem forçados a assumir custos elevados de deslocação aérea.

Os objetivos específicos foram contribuir para a transição do conhecimento arqueológico, do meio científico para o público em geral e, necessariamente, captar o seu interesse e abrir caminho à sua sensibilização para o papel da Arqueologia na comunidade.

A Arqueologia é uma ciência muito recente nos Açores (NETO, 2018), pelo que urge um posicionamento de proximidade dos técnicos e investigadores com o contexto social em que se integram. Particularmente numa altura de reabilitação urbana dos centros históricos, em cujos projetos e execuções não era comum, até há bem pouco tempo, a participação ativa e a intervenção de arqueólogos e arqueólogas.

Não deixou de ser também nosso desígnio concreto apoiar o discernimento público para o questionamento de afirmações, alegadamente científicas, sem suporte de facto e sensacionalistas, e de alegados achados arqueológicos, que têm encontrado acolhimento na comunicação social regional, nacional e internacional, inclusive integrando a produção de documentários e difusão através dos canais de televisão, que mais facilmente chegam ao público em geral, e captam a sua atenção.

Maior dificuldade de despertar o público têm os resultados das investigações arqueológicas com seriedade e respeito pela deontologia científica. Desta feita, e constatada a carência de eventos de divulgação didática e acessível dos resultados de trabalhos 
arqueológicos, procedemos à criação das "Conversas de Arqueólogos".

Cumpria-nos promover o esclarecimento do público, sem cair no erro de entrar em determinadas polémicas e enredamentos. (Tabelas 1, 2)

\section{EFEMÉRIDES}

As "Conversas de Arqueólogos" assinalaram as seguintes efemérides, com os respetivos convidados/ as e temas associados:

- Noite Europeia dos Museus (16 de maio);

- Dia dos Açores (1 de junho);

- Dia Mundial dos Oceanos (8 de junho);

- Dia Internacional do Refugiado (20 de junho)

(Figura 5).

\section{PARCERIAS INSTITUCIONAIS}

Algumas das "Conversas de Arqueólogos" foram realizadas em parceria institucional, sem implicação de custos para as instituições envolvidas, com:

- Museu do Côa (16 de maio);

- Governo dos Açores / Direção Regional da Cultura dos Açores (1 de junho);

- Instituto Politécnico de Tomar (8 de junho);

- Associação dos Arqueólogos Portugueses (26 de junho) (Figura 6);

- Câmara Municipal de Vila Franca do Campo (29 de junho).

A parceria institucional, para além de prestigiar os eventos, beneficia largamente a divulgação das iniciativas, na medida em que se solicitou a disseminação dos cartazes respetivos e links associados. É também um ponto de partida para futuras cooperações, pois proporciona um primeiro contacto formal e a existência de precedente relacional.

\section{CONSIDERAÇÕES PRÁTICAS DE EXECUÇÃO}

Dada a perspetiva didática que se pretendia, e pese embora se careça de trabalhos de referência de Didática da Arqueologia, ou de Didática Digital, socorremo-nos da interdisciplinaridade, nomeadamente de algumas publicações de Didática da História (ALARCÃO, 2002; FERREIRA, 2010; PROENÇA, 1992) e de Didática da Geografia (BRITO e POEIRA, 1991). A escolha da designação foi propositadamente restritiva, na medida em que, tratando-se de conversas "de" arqueólogos, somente teriam voz os técnicos e as técnicas da referida área, numa altura e num contexto geográfico onde, como referimos, têm surgido alegadas investigações e alegados achados arqueológicos por não arqueólogos.

Foi uma definição com propósito retificativo e não propriamente discriminatório na aceção de inferiorização. Recorrer ao próprio colherim, símbolo associado ao nome do evento (ver figuras 5, 6 e 7), também não foi inocente. Sobretudo tendo em conta que se trata de um instrumento, não só mas também, de retificação dos perfis estratigráficos, para uma melhor perceção das diferenças das camadas, da inversão estratigráfica e das intrusões.

Nunca é excesso recordar que a investigação arqueológica é feita por arqueólogos credenciados, não obstante do seu carácter interdisciplinar e da perspetiva de envolvimento de participantes não académicos em trabalhos arqueológicos. Essa mensagem ficou sempre explícita e implícita nas conversas.

A escolha dos convidados, por proposta do moderador e aprovação do Presidente do Conselho de Administração da Fundação Sousa de Oliveira, não foi arbitrária. Muito menos, infelizmente, incluiu todos os arqueólogos ou arqueólogas que se entendia deverem ser convidados.

Por opção, as reuniões do Zoom da "Conversa de Arqueólogos" apenas integravam os intervenientes diretos (moderador e convidado), podendo a assistência interagir através dos comentários no Facebook. Foi aberta uma exceção, para o dia 29 de maio, cujo tema era "Arqueologia e Imaginário - fakenews de uma Ciência” (Figura 7), com André Donas-Botto, para que se possibilitasse um esclarecimento mais direto de algumas dúvidas de eventuais interessados, acerca das complexidades do processo científico na área, e das suas especificidades.

Procurou-se também, nesta sessão, esclarecer as diferenças entre o que representa a Arqueologia no imaginário popular e o que é efetivamente na prática (HOLTORF, 2007).

A interação da assistência processou-se geralmente através dos comentários do Facebook, na transmissão em direto, sendo que por essa via ficava inviabilizada a participação ativa dos espectadores sem registo na rede social. No entanto, a visualização do direto era sempre possível, mesmo para quem não tinha perfil de Facebook.

Não houve qualquer recurso a profissionais intérpretes de língua gestual portuguesa por indisponibi- 
lidade financeira, não se tendo, portanto, concretizado a inclusão de deficientes auditivos. Nesse aspeto, as "Conversas de Arqueólogos" ficaram aquém do expectável, em termos do que perspetivava - inclusão e acessibilidade integrais.

Todos os convidados iniciavam a conversa, por desafio do moderador, com uma breve explicação do conceito de "Arqueologia" e com as memórias de um sítio arqueológico à escolha, começando com a expressão tradicional de conto de histórias, "Era uma vez...”, procurando apelar ao espírito criativo e didático do orador, que era previamente e atempadamente informado.

As sessões tiveram duração de entre 45 minutos a uma hora e trinta minutos, não se tendo estipulado duração.

Junto dos convidados, apelou-se sempre a um espírito de síntese e de simplificação, o que nem sempre se tornou possível. A simplificação era, por vezes, incentivada pelo moderador, aquando da utilização por parte do convidado ou convidada de terminologia técnica demasiado específica, e por isso muitas vezes inacessível ao público não académico.

Nos cartazes era sempre indicado o fuso horário, junto com a hora agendada, tendo em conta que a assistência poderia estar em qualquer parte do mundo. Mesmo Portugal tem diferença de fuso horário, visto que na área continental e arquipélago da Madeira soma uma hora à do arquipélago dos Açores. Era necessário prestar essa informação, chamando à atenção para o desfasamento horário. Recomenda-se procedimento análogo para eventos similares.

A hora foi padronizada praticamente nas 18 hoo (Fuso horário +oo Açores), embora houvesse flexibilidade, o que aconteceu por duas vezes, nomeadamente por razões de quotidiano familiar, e uma por motivo de coincidir com a efeméride (Noite Europeia dos Museus). Há que descartar a rigidez desnecessária neste tipo de eventos, sobretudo quando se tratava de uma experiência nova, quer para o promotor, quer para o moderador, quer para a maioria dos convidados.

A última sessão foi realizada com o apoio da Câmara Municipal de Vila Franca do Campo, e em formato presencial, transmitida em direto para o Facebook da Fundação Sousa de Oliveira e, em simultâneo, para o Facebook da autarquia ${ }^{7}$.

7. https://www.facebook.com/CamaraMunicipalDeVilaFrancaDoCampo/
Com os custos assumidos pela Câmara, recorreu-se a uma produtora audiovisual e o espaço escolhido foi o Salão Nobre do Solar dos Viscondes do Botelho, hoje Museu Municipal de Vila Franca do Campo (Figura 8).

Não se tratando de arqueólogos, à exceção do moderador, participaram na conversa o Presidente do Conselho de Administração da Fundação Sousa de Oliveira, Carlos Melo Bento, o Presidente da Câmara Municipal de Vila Franca do Campo, Ricardo Rodrigues, e o cirurgião ortopedista António Tavares de Melo.

A iniciativa propunha-se, por um lado, a recuperar memórias dos participantes nas escavações em Vila Franca do Campo, nos anos 70, com Manuel Sousa de Oliveira e, por outro, a incentivar ao regresso presencial aos espaços de fruição cultural, ainda que com as condicionantes ainda em vigor.

A realização das "Conversas de Arqueólogos" implicou um custo de $€_{34,42 \text {, correspondente a duas }}$ subscrições mensais de Plano Profissional da plataforma Zoom. Os cartazes e restantes elementos gráficos de divulgação foram executados com meios próprios.

Todas as gravações das "Conversas de Arqueólogos" estão disponíveis no separador de "Vídeos" da página de Facebook da Fundação Sousa de Oliveira.

\section{IMPACTO NA COMUNICAÇÃO SOCIAL}

Tal como Sousa de Oliveira durante as escavações em Vila Franca do Campo (BENTO, 1990), bem como nos "Clubes de História", procurou-se divulgar atempadamente a informação junto da comunicação social, nomeadamente da imprensa, que com frequência semanal registava referência aos eventos, quer anunciando, quer registando o balanço (Correio dos Açores, 16/o6/2020).

Da mesma forma, o moderador foi convidado a falar sobre a iniciativa, no programa Açores Hoje, da jornalista Vera Santos, na RTP-Açores, no dia 29 de maio.

\section{CONSIDERAÇÕES FINAIS}

A adaptação e simplificação de conceitos científicos exigiu uma dimensão de capacidades e um esforço que, provavelmente, colheu benefícios da obrigatoriedade do recurso às tecnologias digitais.

Em condições de segurança sanitária, com recurso a um diálogoacessível, predominantemente direciona- 
do para a população não académica, foram realizadas, no espaço de dois meses, dezassete sessões, tematicamente diversas e cronologicamente abrangentes. Proporcionou-se ao público em geral, e ao açoriano em particular, a fruição do Património Cultural, e a perceção genérica do processo científico da Arqueologia, não procurando forçosamente desmanchar estereótipos do público perante a área, mas capitalizando-os, de forma construtiva, para uma aproximação do público ao saber.

Sobretudo, promoveu-se o alargamento de horizontes, num contexto desfavorável. Tornou-se a adversidade numa oportunidade.

Ficou evidente também que ao arqueólogo convém ser, para além de um cientista, um divulgador da sua ciência, razão pela qual porventura se justifica a integração de disciplinas como Didática e Pedagogia nos programas curriculares universitários, das Licenciaturas em Arqueologia, de modo a poder autonomamente conceber, com o apoio da tecnologia digital, instrumentos de transição do conhecimento da esfera académica para a fruição pública, plena e acessível.

\section{AGRADECIMENTOS}

Um agradecimento pessoal à Fundação Manuel Sousa de Oliveira, pela confiança.

Um cumprimento particular a todos os convidados e convidadas da "Conversa de Arqueólogos".

\section{BIBLIOGRAFIA}

ALARCÃO, Isabel (2002) - De que se fala quando se fala de Didáctica. in MEDEIROS, EMANUEL OLIVEIRA (Ed.) I Encontro de Didácticas nos Açores. Universidade dos Açores ed. Ponta Delgada. p. 31-48.

BAIROS, Sandra Sousa (2018) - Contributo para a criação do serviço educativo da Fundação Sousa d'Oliveira - o desenvolvimento de laços entre o espólio arqueológico e os públicos mais jovens. Ponta Delgada: Universidade dos Açores (Dissertação de Mestrado).

BENTO, Carlos Melo (1990) - Escavações Arqueológicas em Vila Franca do Campo (1967-1982). Ponta Delgada: Associação Arqueológica do Arquipélago dos Açores.

BRITO, Raquel Soeiro de; POEIRA, Maria de Lurdes (1991) - Didáctica da Geografia. Lisboa: Universidade Aberta.

Diário dos Açores (2018) - Câmara de Ponta Delgada adquire 50 exemplares das 12 edições do boletim "O Pioneiro" - (16 dez. 2018). 7 .
Correio dos Açores (2020) - Combater as fakenews de que nos Açores está a Atlântida ou uma civilização fenícia - (16 jun. 2020). 4-5.

Estatutos da Fundação Doutor Manuel Sousa de Oliveira. Diário da República n.ำ 276/o4 - III Série (26197-26198).

FERREIRA, Octávio Amado (2010) - Ao serviço da didáctica da História: trabalhos de apoio ao ensino da História. Coimbra: Minerva.

HOLTORF, Cornelius (2007) - Archaeology is a Brand! The meaning of Archaeology in Contemporary Popular Culture. New York: Archeopress.

NETO, José Luís (2018) - Arqueologia nos Açores - uma breve História. Angra do Heroísmo: Instituto Açoriano de Cultura.

PROENÇA, Maria Cândida (1992) - Didáctica da História. Lisboa: Universidade Aberta.

SOUSA, Sílvia Fonseca e (2009) - A Museologia na Ilha de São Miguel: 1974-2008. Ponta Delgada: Universidade dos Açores (Dissertação de Mestrado).

VIANA, Abel; OLIVEIRA, Manuel Sousa D' (1954) "Cidade Velha" de Santa Luzia: Viana do Castelo. Guimarães: Revista de Guimarães. 

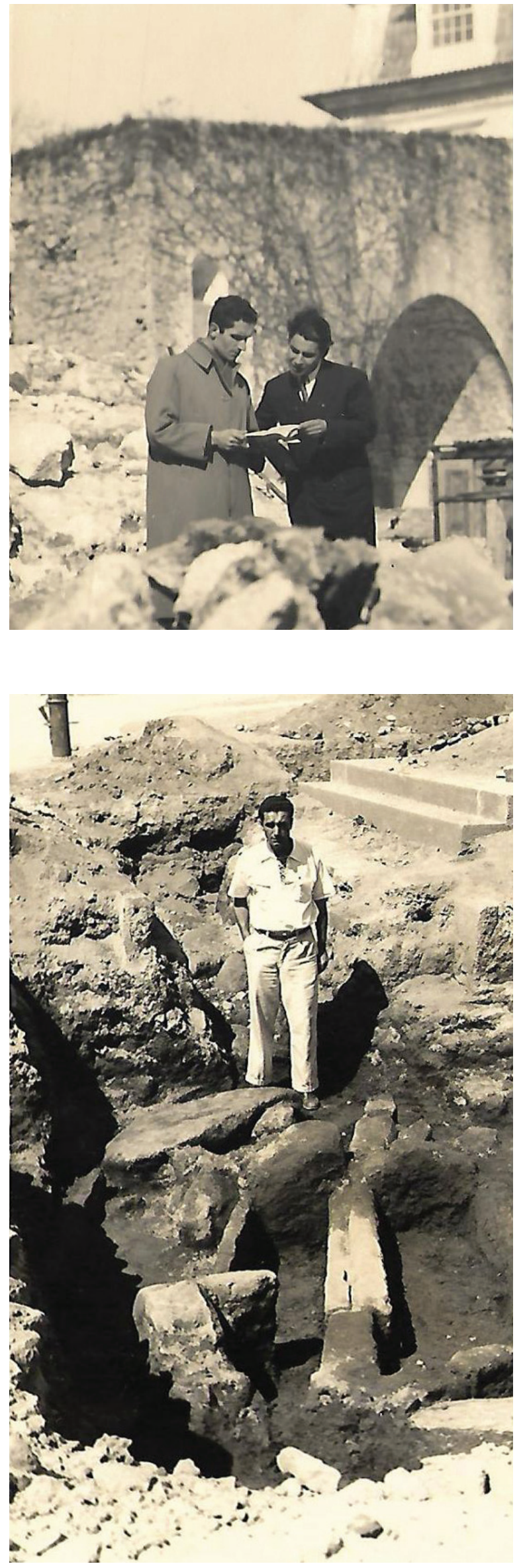

Figura 1 - 1947: Sousa de Oliveira (à esquerda), no atual Largo D. Dinis, em Coimbra. Arquivo FSO.

Figura 2 - 1952: Manuel Sousa de Oliveira numa escavação em Viana do Castelo. Arquivo FSO. 


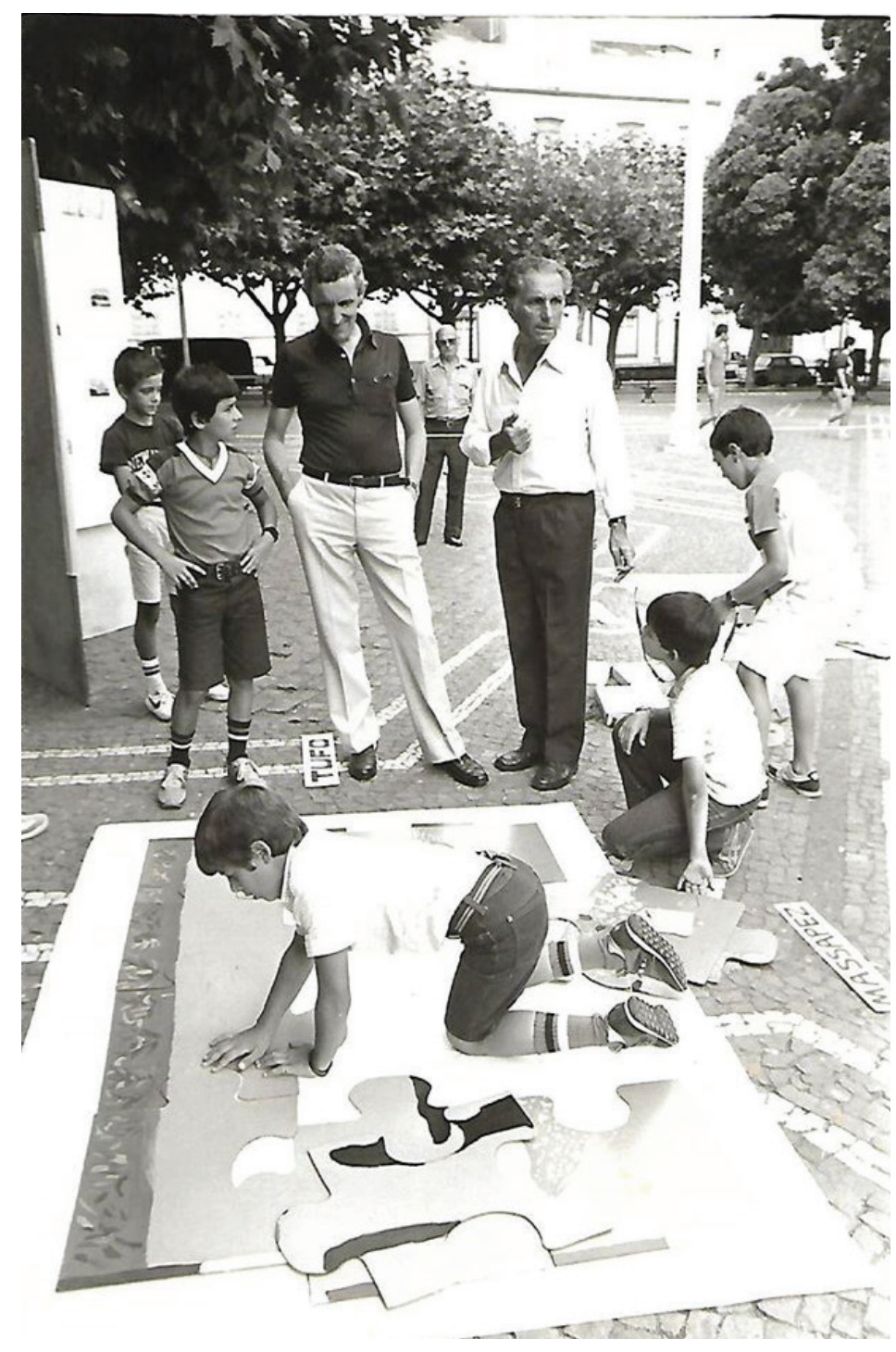

Figura 3-1985: Os puzzles de materiais e estratigrafia arqueológica. Em segundo plano, Mota Amaral (à esquerda) e Sousa e Oliveira (à direita). Arquivo FSO.

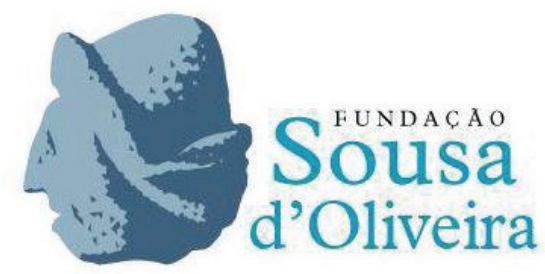

Figura 4 - Logótipo da Fundação Sousa de Oliveira. Arquivo FSO. 


\begin{tabular}{|l|l|l|l|}
\hline Dia & Hora & Convidado/a & Título \\
\hline 8 & $18 \mathrm{~h}$ & Catarina Quinteira & Da Escavação para o Museu - Arqueologia para o Público \\
\hline 11 & $18 \mathrm{~h}$ & José d’Encarnação & Quando as Pedras Falam - A Ciência da Epigrafia \\
\hline 15 & $18 \mathrm{~h}$ & João Gonçalves Araújo & Cidade da Horta - Arqueologia e Urbanismo \\
\hline 16 & $20 \mathrm{~h} 30$ & Luís Simões Luís & O que é a Arte Rupestre? \\
\hline 22 & $18 \mathrm{~h}$ & $\begin{array}{l}\text { Liliana Carvalho } \\
\text { Susana Henriques }\end{array}$ & $\begin{array}{l}\text { Mil Esqueletos e Um Hospital: Outras Histórias do Castelo } \\
\text { de S. Jorge }\end{array}$ \\
\hline 25 & $18 \mathrm{~h}$ & Santiago Macias & Arqueologia e Política - da Teoria à Prática \\
\hline 29 & $18 \mathrm{~h}$ & André Donas-Botto & Arqueologia e Imaginário - Fakenews de uma Ciência \\
\hline
\end{tabular}

Tabela 1 - Calendarização / maio 2020

\begin{tabular}{|c|c|c|c|}
\hline Dia & Hora & Convidado/a & Título \\
\hline 1 & $18 \mathrm{~h}$ & $\begin{array}{l}\text { José Luís Neto } \\
\text { Pedro Parreira }\end{array}$ & Arqueologia nos Açores: Passado, Presente e Futuro \\
\hline 5 & $17 \mathrm{~h}$ & Tânia Casimiro & $\begin{array}{l}\text { "Isso nem é Arqueologia..." - Arqueologia Contemporânea } \\
\text { em Portugal }\end{array}$ \\
\hline 8 & $18 \mathrm{~h}$ & $\begin{array}{l}\text { Alexandra Figueiredo } \\
\text { Cláudio Monteiro }\end{array}$ & Conservação do Património Subaquático: o dia de amanhã \\
\hline 12 & $18 \mathrm{~h}$ & Alexandre Monteiro & Os naufrágios nos Açores \\
\hline 15 & $18 \mathrm{~h}$ & Luís Campos Paulo & $\begin{array}{l}\text { Tecnologia e Arqueologia - A preservação digital } \\
\text { do Património }\end{array}$ \\
\hline 19 & $18 \mathrm{~h}$ & Jacinta Bugalhão & Arqueologia das Catástrofes - Lisboa 1755 \\
\hline 20 & $18 \mathrm{~h}$ & Rui Gomes Coelho & Arqueologia das Migrações Contemporâneas \\
\hline 22 & $17 \mathrm{~h}$ & João Luís Sequeira & Arqueologia Industrial - Um conceito intemporal \\
\hline 26 & $18 \mathrm{~h}$ & José Morais Arnaud & O Associativismo e a Arqueologia \\
\hline 29 & $18 \mathrm{~h}$ & $\begin{array}{l}\text { Carlos M. Bento } \\
\text { Ricardo Rodrigues } \\
\text { António T. Melo }\end{array}$ & Eu escavei com o Sousa! \\
\hline
\end{tabular}

Tabela 2 - Calendarização / junho 2020 


\section{streaming CONVERSA IDE ARQUEÓLOOAOS}

com Diogo Teixeira Dias

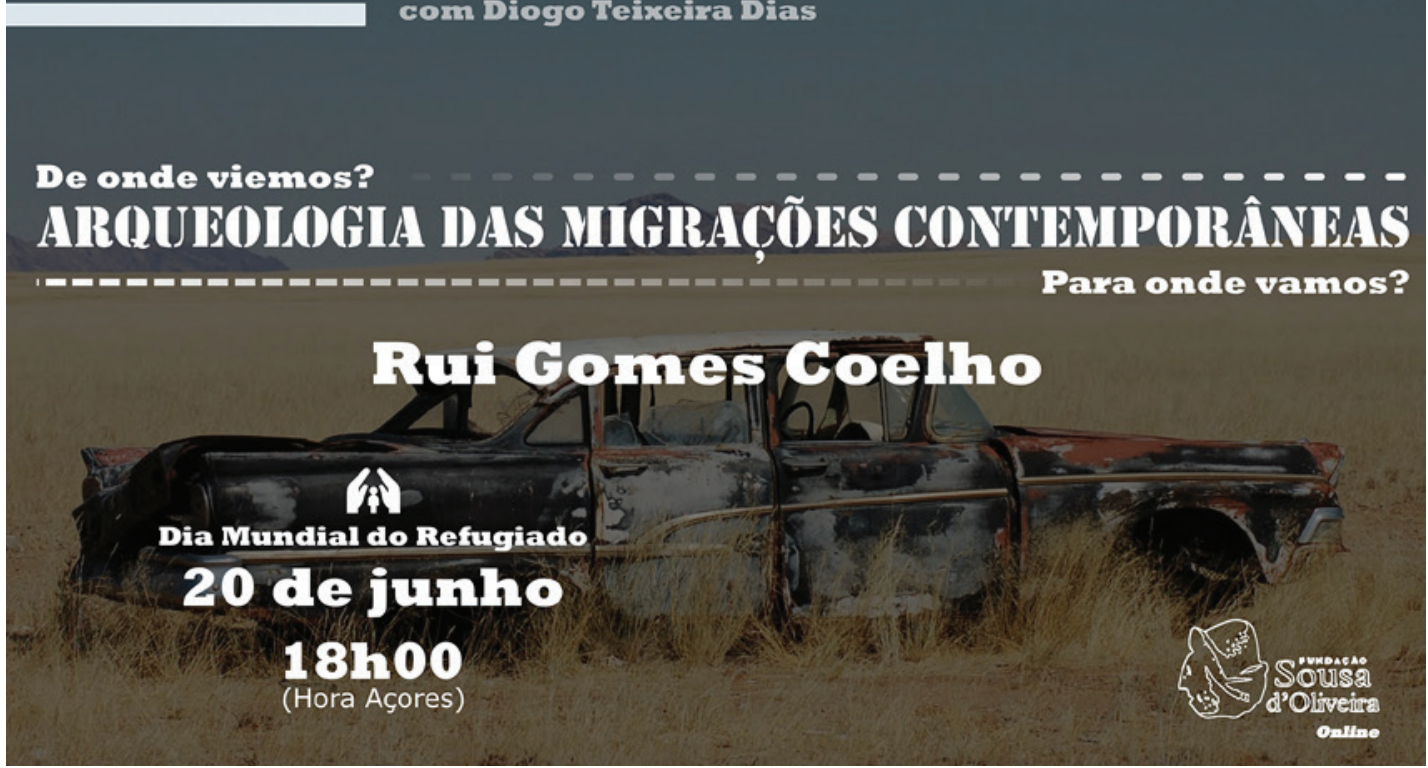

Figura 5-Cartaz de uma “Conversa de Arqueólogos” assinalando uma efeméride (Dia Mundial do Refugiado), com a referência acima da data e hora.

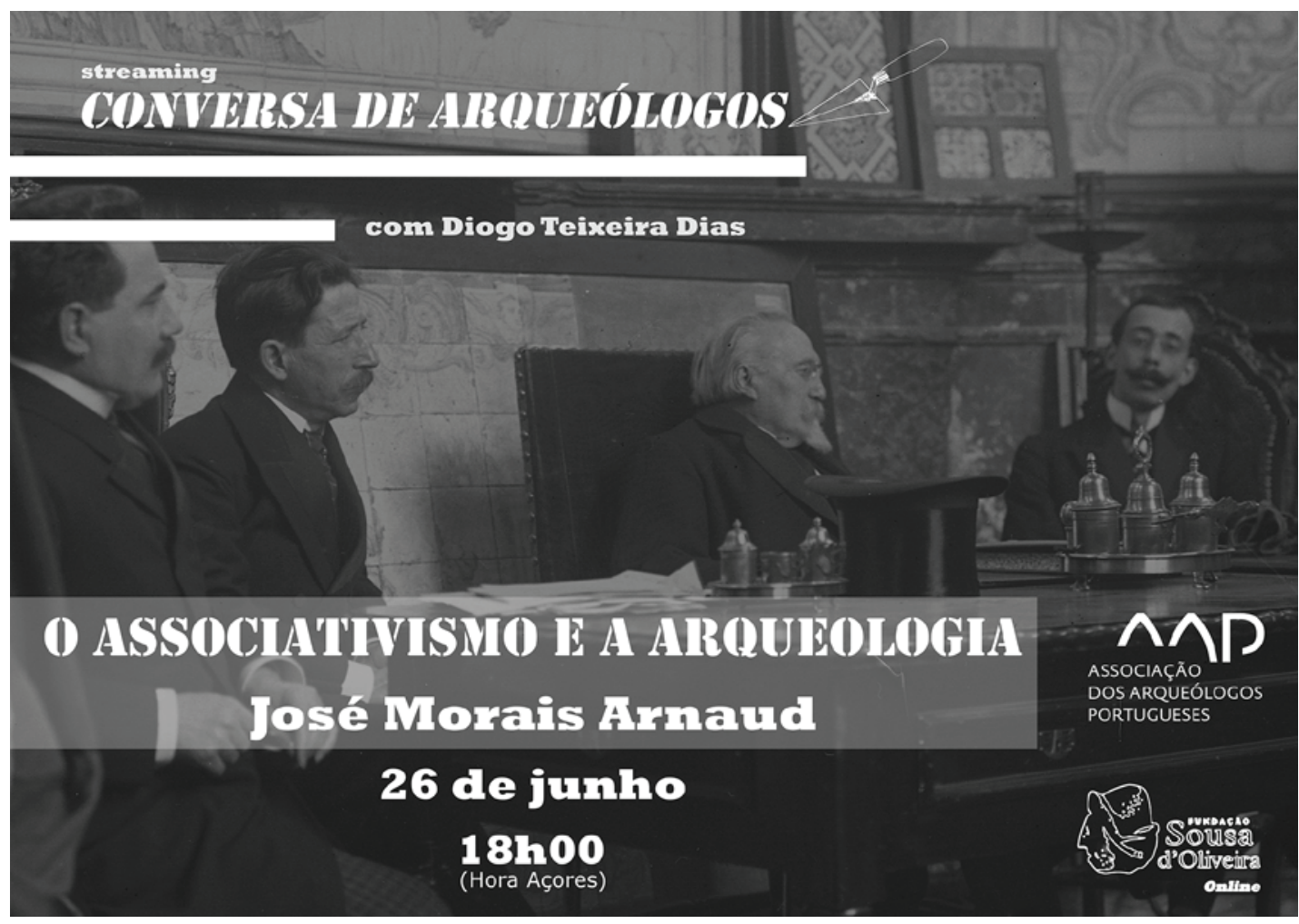

Figura 6- Cartaz de uma "Conversa de Arqueólogos” indicando uma parceria institucional (Associação dos Arqueólogos Portugueses). 


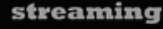 \\ CONVERSA DE ARQUUÉLIOGOS}

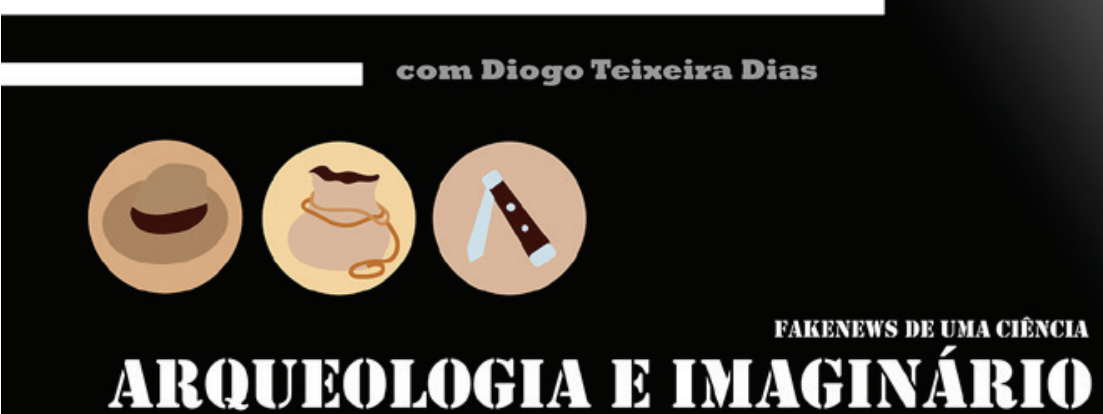

ANIRÉ́ DONAS-BOTYO

29) MAIO

181100

(Hora Açores)

f

HTTPS://WWW.PACEBOOK.COM/FUNIDACAOSOUSADOUIVEIRA/

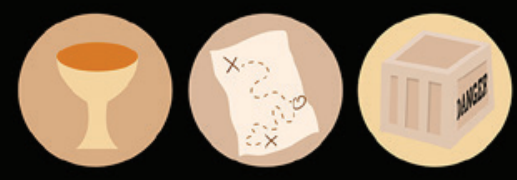

Figura 7-Cartaz da iniciativa “Arqueologia e Imaginário - fakenews de uma Ciência”, com André Donas-Botto

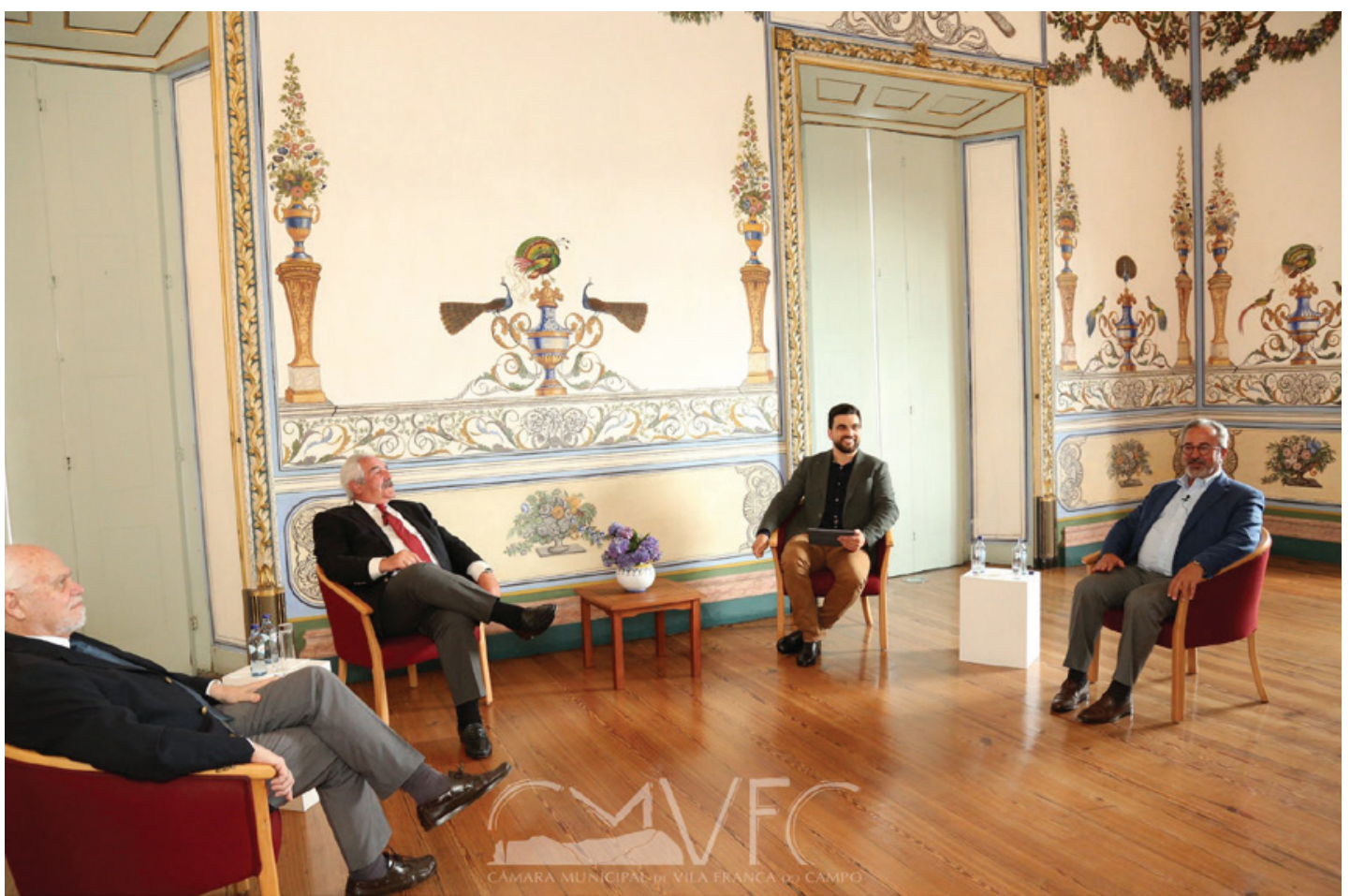

Figura 8 - Encerramento das “Conversas de Arqueólogos”, na sessão de memórias da Arqueologia “Eu escavei com o Sousa!”. CMVFC. 



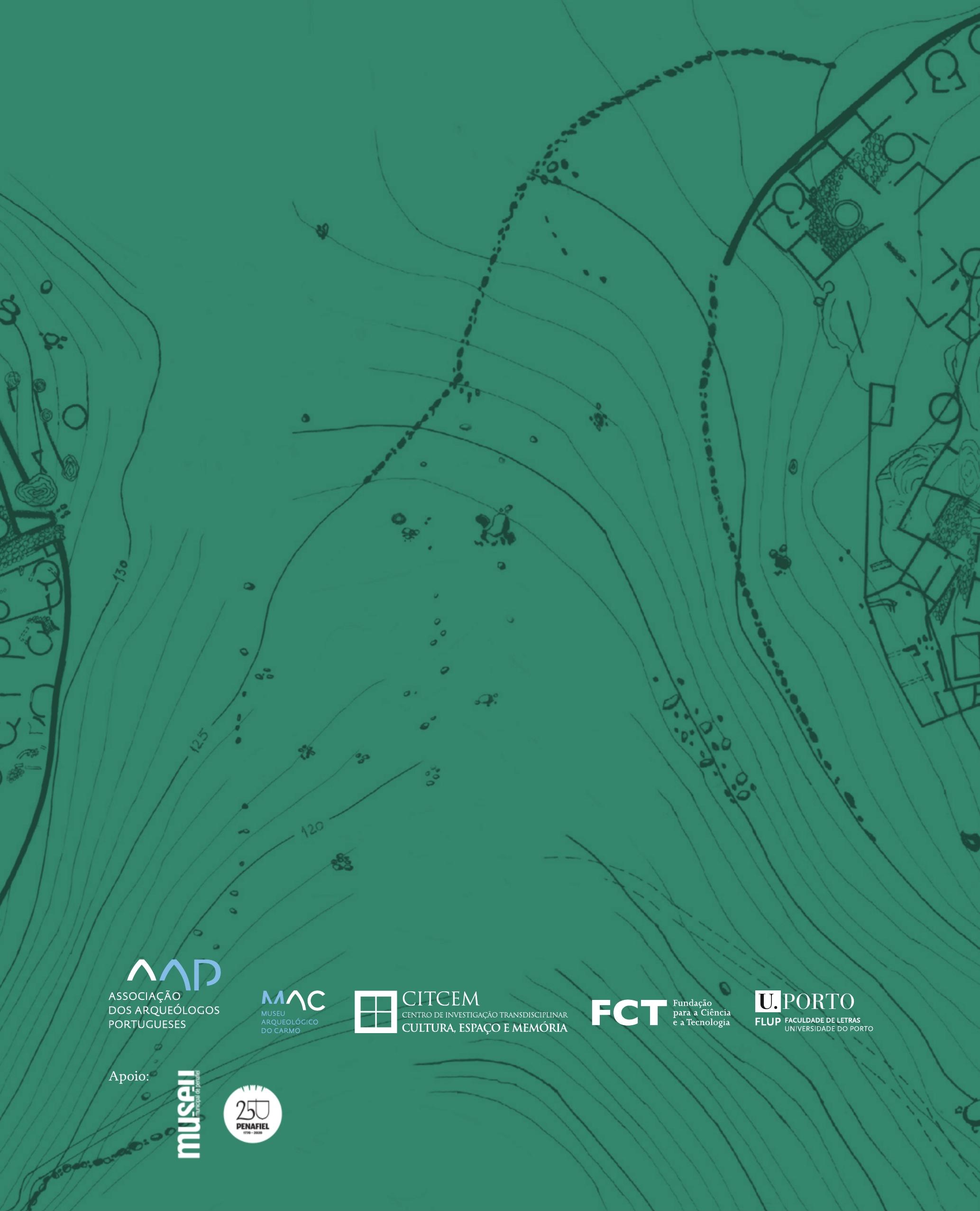

